\title{
KAIDAH AL-AMR WA AL-NAHYI
}

\author{
Oleh: Abdul Kallang
}

\begin{abstract}
Abstrak
Various interpretations expressed by our ulalma are only human beings who have to do with which they must follow, the question of the interpretation of the Koran which is very diverse with various methods available in interpreting the Koran. With the existence of the Qur'anic sciences which have been formatted by our predecessor scholars, we only have to develop the method. Sala one method that I want to discuss in the rules of the science of interpretation is the issue of ال درو النهي in the Qur'an and the application of the tesk and its context in seeing the reality that exists.
\end{abstract}

\section{PENDAHULUAN}

Umat Islam sadar dan mengakui bahwa Alquran adalah mukjizat yang sangat luar biasa bagi umat Islam yang yang dapat dilihat dan dirasakan sampai sekarang selalu diperkuat oleh ilmu pengetahuan. Alquran diturungkan Allah kepada Rasulullah Saw sebagai mukjizat skaligus petunjuk bagi umat Islam dibelahan dunia ini fungsinya untuk mengeluarkan manusia dari suasana yang gelap gulita meneuju situasi yang lebih baik dan penuh cahaya ${ }^{1}$.

Alquran adalah karya sastra yang sangat indah bahasanya mempunyai ragam ilmu pengetahuan penafsirannya selalu sesuai dengan kondisi zaman di sekelilingnya $^{2}$, makin dibaca makin kaya arti, makna serta penafsirannya. Sebagai kitab hidayah sepanjang zaman, Alquran, memuat informasi-informasi dasar tentang berbagai masalah, sebagaimana diketahui bersama bahwa problematika umat manusia dalam dinamika kehidupan tidak pernah habis sepanjang perkembangan ilmu pengetahuan serta penafsiran tidak pernah kering dalam kehudupan umat manusia selama kehidupan selalu berputar dan mempunyai situasi yang berbeda dari situasi sebelumnya maka begitu pula tadabbur alquran selalu dinamis menghadapi persoalan yang ada selama Alquran itu tidak dilegitimasi degan persoalan yang ada.

\footnotetext{
${ }^{1}$ Manna' khalil al-Qattan. Studi IImu-Ilmu Al-Quran, (cet. VI; Bogor: Pustaka Litera Antar Nusa, 2001). H. 1

${ }^{2}$ Umar Shihab, kontekstualitas Alquran kajian tematik atas ayat-ayat hokum dalam Alquran,(cet. I; Jakarta: Penamadani, 2003), h. xx
} 
Alquran secara teks memang tidak berubah tetapi penafsirannya selalu berubah sesuai dengan konteks dan waktu disekitarnya, oleh karena itu Alquran selalu terbuka untuk dianalisis, dipresepsi, diinterpretasi (ditafsirkan) dengan berbagai alat, metode, dan pendekatan untuk menguak isinya, berbagai metode dan tafsir yang digunakan sebagai jalan untuk membedah isi Alquran tersebut ${ }^{3}$.

\section{B. PEMBAHASAN}

\section{Pengertian Al-Amr Wa Al-Nahyu}

a. Pengertian al-Amr

perintah adalah suatu urusan yang berantonim dengan larangan (النهي) yang sebetulnya mempunyai kesamaan yaitu sama-sama tuntutan yang satunya anjuran sedangkan yang satunya lagi pelarangan ${ }^{4}$. Setiap ada perintah maupun larangan mempunyai karinah tertentu yang mempunyai implikasi yang mempunyai efek tertentu ${ }^{5}$.

Menurut bahasa adalah perintah itu kebalikan dari larangan, yang berarti tuntutan. Sedankang menurut istilah sebahagian mereka memberitahukan dengan berdasarkan perkataannya yaitu memulai pekerjaan dengan perkataan pada bentuk على وجه الاستعلاء عebawah. Ada yang mengatakan tinggi atau dari atas kebah kaeda ini bukan pada semua sisi bahkan mereka bertentangan terhadapnya sebagaimana mereka berbeda pada syarat-syarat yang tinggi artinya adanya perintah itu lebih tinggi kedudukannya atau tingkatannya daripada apa yang diperintahkan ${ }^{6}$.

Kewaiban hukum التكليفى bermakna kehususan yang terdapat alamat atau tanda-tanda didalamnya yang harus diketahui seperti: صيغة الامر itu mutlak jika dihubungkan dengan tanda-tanda maka sesungguhnya itu wajib sebagaimana umumnya. Contoh-contohnya yang terdapat dalam Alquran sebagai berikut:

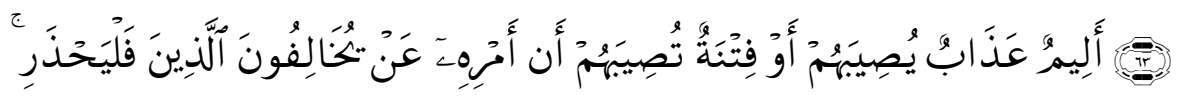

Terjemahnya: Maka hendaklah orang-orang yang menyalahi perintah-Nya takut akan ditimpa cobaan atau ditimpa azab yang pedih.

${ }^{3}$ Ibid., h. 3

${ }^{4}$ Abi Husein Ahmad Bin Faris Bin Zakiyah, Makayisu Al-Lugah, juz I (Daru al-Fikri,). H. 137

${ }^{5}$ Khalid bin Usman al-Tsabit, Muhtasar Fi Qawaid Al-Tafsir(Dar Ibnu Affan Li Al-Nasyri Wa AlTauziq, 1996) h. 15

${ }^{6}$ Khalid Utsman al-Tsabit, Qawaid al-Tafsir, jilid 2 (cet. I;Al-Mumlikat Al-Arabi Saudi: Dar Ibnu Affan Li Al-Nasry Wa Al-Tauzig, 1997 M). h. 478 
Dalam ayat dapat dipahami bahwa masalah ketetiban atas hukum itu berbedabeda dengan perintah karena sesungghnya perintah itu wajib.

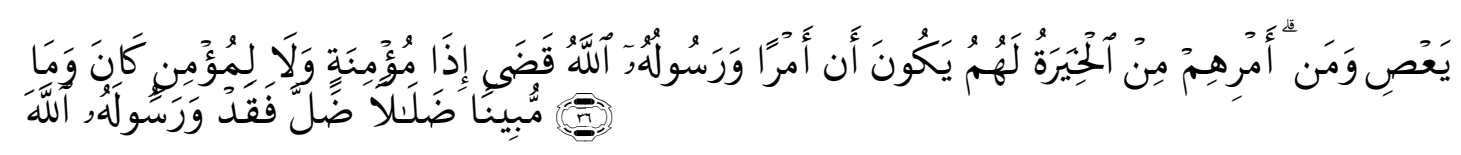

Terjemahnya:

Dan tidaklah patut bagi laki-laki yang mukmin dan tidak (pula) bagi perempuan yang mukmin, apabila Allah dan rasul-Nya Telah menetapkan suatu ketetapan, akan ada bagi mereka pilihan (yang lain) tentang urusan mereka. dan barangsiapa mendurhakai Allah dan rasul-Nya Maka sungguhlah dia Telah sesat, sesat yang nyata.

Dalam ayat ini dapat dipahami bahwa manfaat kebaikan ketika ditetapkan الامر itu bersamaan dengan diwajibkannya perintah tersebut. Dalam sunnah dikatakan bahwa dalil perintah itu menunjukkan keharusan atau kewajiban?

lafal khusus yang mengacu kepda perintah untuk berbuat. Ulama usul fikih mengacu kepada perintah untuk berbuat. Ulama ushul fikhi mendefinisikan الامر dengan lafal yang menngandung tuntutan untuk berbuat dari pihak yang lebih tinggi. Berdasarkan definisi ulama usul fikih tersebut apabila tuntutan untuk melaksanakan suatu perbuatan itu datang dari pihak yang lebih rendah kepada yang lebih tinggi (diatasnya), maka tidak dinamakan الامر tetapi bisa bermkna harapan dan doa dan sejenisnya. Pendapat yang mengatakan bahwa perintah itu harus dari atas kebawah dikemukakan ulama mazhab Hanafi dab Hanbali akan tetapi ulama mazhab Maliki dan Syafi'I berpendapat bahwa lafal الامر itu tidak disyaratkan datangnya dari pihak yang lebih tinggi, menurut mereka lafal الامر mengadung perintah untuk melakukan suatu perbuatan, tampa melihat darimana datangya perintah tersebut ${ }^{8}$.

\section{b. Pengertian An-Nahyu}

An-Nahyu asal katanya النون, الهاء, الياءalnya fiil sahih menunjukkan kepada tujuan dan penyampaian. Diantaranya saya melarang daripadanya suatu khabar: saya sampaikan kepada bapaknya dan saya melarang semua sesuatu yang akan sampai kepadanya dan diantaranya saya melarang apa-apa dari padanya dan itu adalah perintah untuk mengerjakannya apa bila saya melarangnya maka itu menjadi larangan bagi kamu suatu tujuan atau yang lainnya dan si fulang melarang kamu menghendaki

\footnotetext{
${ }^{7}$ Khalid Utsman al-Tsabit, Qawaid al-Tafsir, jilid 2

${ }^{8}$ Dahlan, Abul Aziz, Ensiklopedi Islam, (cet. I; Jakarta: Ichtiar Baru Van Hoeve, 1996), h. 108
} 
suatu hajat hingga dia melarang dari padanya, meninggalkan, menutupnya atau tidak. Seakan-akan dia mencegah dirinya dari tuntutannya ${ }^{9}$.

Menurut bahasa adalah lawan kata dari perintah وهاه, ينهاه, نهيا, (saya melarang, dia melarang, larangan) فانتهى و تتاهي : كف (menahan/mencegah) sedangkan menurut istilah yaitu tuntutan mencegah untuk melakukan suatu perbuatan. Dan dikatakan yaitu perkataan yang menghendaki daripadanya orang yang barkata itu meninggalkan perbuatan tanpa dirinya.

Manurut Bahasa الأمر adalah kebalikan dari النهي sedangkan menurut istilah adalah: sebahagian mereka mengetahui yang dimulai dengan fiil berdasarkan pada bentuk yang asalnya dari atas. Atau adanya perinta itu lebih tinggi tingkatannya dari pada halnya. Perintah itu mutlak dan menghendaki wajibnya

Pada intinya perintah Allah itu terbagi dua yaitu untuk mewujudkan perbuatan dan meninggalkan perbuatan. Dengan demikian larangan Allah pun pada hakekatnya perintah Allah yaitu untuk meninggalkan perbuatan. Ketika hendak melaksanakan perintah Allah baik mewujudkan maupun meninggalkan suatu perbuatan, hendaknya terlebih dahulu mengetahui hakikat perintah tersebut. Apakah perintah Allah itu untuk memenuhi kewajiban terhadap Allah ataukah terhadap sesama manusia ${ }^{10}$

\section{Fungsi Dan Aplikasinya Dalam Alquran}

Sebagaimana diketahui bersama bahwa banyak hal dalam Alquran yang tidak dapat dijalankan bila tidak diperoleh penjelasannya. Keadaan ini menunjukkan bahwa penjelasan-penjelasan Nabi saw. Tidak dapat dipisahkan dari pemahaman maksud isi kandungan Alquran. Beliau adalah satu-satunya menusia yang mendapat wewenang penuh untuk menjelaskannya. Penjelasan beliau dapat dipastikan kebenarannya ${ }^{11}$.

Dalam hal ini penulis mencoba melihat aplikasi metode tafsir dalam membahas Alquran menenai kata الاهر والنهى dan aspek-aspeknya.

a. Lafal الامر

Mengenai lafal الامر ini ulama usul fikih berbeda pendapat tentang kandungan yang dikehendaki lafal الامر tersebut apakah untuk suatu kewajiban atau untuk satu

\footnotetext{
${ }^{9}$ Abi Husain Ahmad bin Faris bin Zakariyah, Makayisu Al-Lugah, h. 359

${ }^{10}$ Abd. Rahman Dahlan, Kaidah-Kaidah Penafsiran Alquran, (cet. II; Bandung: Mizan, 1998). H. 304

${ }^{11}$ Al-fatih Suryadilaga Pengantar Abd. Muin Salim, Metodologi Ilmu Tafsir, (Cet. I; Yogyakarta: Teras, 2005), h.97
} 
anjuran saja. Dalam pengertian bahasa menurut Said Ramadhan Al-Buti ${ }^{12}$ lafal الامر ini mengandung beberapa pengertian sebagai berikut:

a). الوجوب (kewajiban) seperti firman Allah swt dalam surat al-Baqarah (2) ayat 43 sebagai berikut:

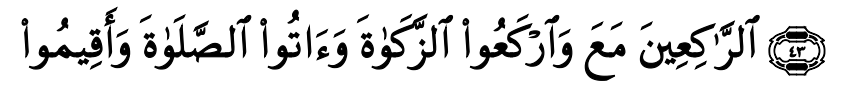

Terjemahnya:

dan Dirikanlah shalat, tunaikanlah zakat dan ruku'lah beserta orang-orang yang ruku'.

Perintah mendirikan shalat dan menunaikan zakat dalam ayat ini bersifat wajib.

b) الندب (anjuran) seperti firman Allah dalam surat an-Nur (24) ayat 33 sebagai berikut:

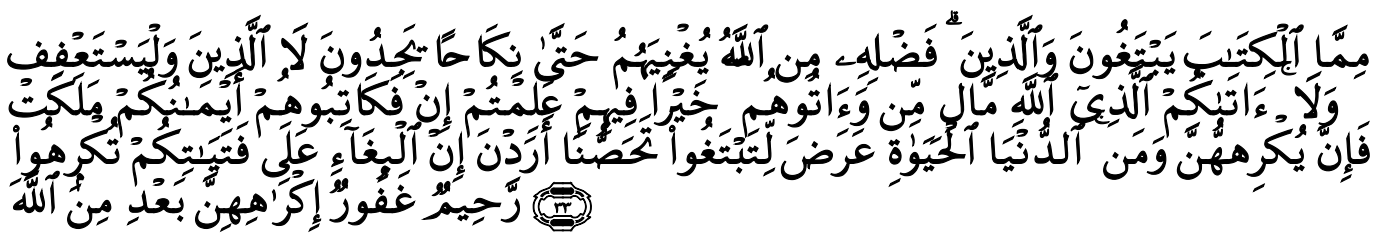

Terjemahnya:

Dan orang-orang yang tidak mampu kawin hendaklah menjaga kesucian (diri)nya, sehingga Allah memampukan mereka dengan karunia-Nya. dan budak-budak yang kamu miliki yang memginginkan perjanjian, hendaklah kamu buat perjanjian dengan mereka ${ }^{13}$, jika kamu mengetahui ada kebaikan pada mereka, dan berikanlah kepada mereka sebahagian dari harta Allah yang dikaruniakan-Nya kepadamu ${ }^{14}$. dan janganlah kamu paksa budak-budak

\footnotetext{
${ }^{12}$ Salah seorang tokoh ushul fikih Suriah

${ }^{13}$ Salah satu cara dalam agama Islam untuk menghilangkan perbudakan, yaitu seorang hamba boleh meminta pada tuannya untuk dimerdekakan, dengan perjanjian bahwa budak itu akan membayar jumlah uang yang ditentukan. Pemilik budak itu hendaklah menerima perjanjian itu kalau budak itu menurut penglihatannya sanggup melunasi perjanjian itu dengan harta yang halal.

${ }^{14}$ untuk mempercepat lunasnya perjanjian itu hendaklah budak- budak itu ditolong dengan harta yang diambilkan dari zakat atau harta lainnya.
} 
wanitamu untuk melakukan pelacuran, sedang mereka sendiri mengingini kesucian, Karena kamu hendak mencari keuntungan duniawi. dan barangsiapa yang memaksa mereka, Maka Sesungguhnya Allah adalah Maha Pengampun lagi Maha Penyayang (kepada mereka) sesudah mereka dipaksa itu ${ }^{15}$.

Dalam ayat ini lafal الامر hanya bersifat الند ب (anjuran) saja

c) الاباحة (Kebolehan) seperti firman Allah swt dalam sural al-Baqarah (2) ayat 60 sebagai berikut:

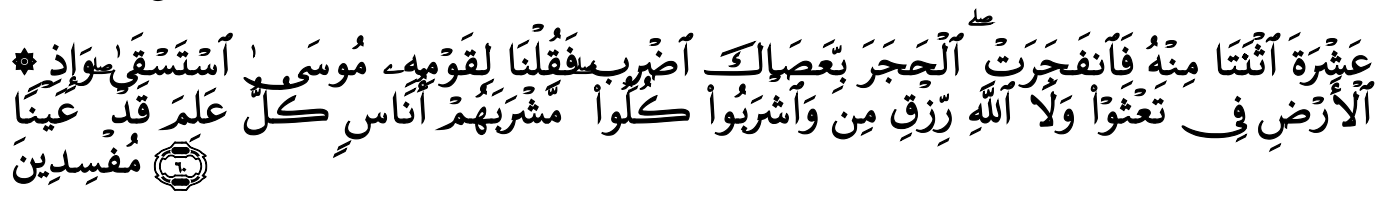

Terjemahnya:

dan (Ingatlah) ketika Musa memohon air untuk kaumnya, lalu kami berfirman: "Pukullah batu itu dengan tongkatmu". lalu memancarlah daripadanya dua belas mata air. sungguh tiap-tiap suku Telah mengetahui tempat minumnya (masing-masing) ${ }^{16}$. makan dan minumlah rezki (yang diberikan) Allah, dan janganlah kamu berkeliaran di muka bumi dengan berbuat kerusakan.

d) الارشاد (Petunjuk) seperti firman Allah swt dalam surat al-Baqarah (2) 282 yang artinya: dan persaksikanlah dengan dua orang saksi dari orang-orang lelaki diantaramu..." ayat ini berbicara dalam masalah muamalah. الامر untuk mendatangkan dua orang saksi dalam ayat ini sifatnya hanya sebagai petunjuk saja karena ada indikator pada ayat sesudahnya (QS. 2:283) yang memalingkan makna الارشاد kepada الامر yaitu: akan tetapi jika sebagian yang lain, maka hendaklah yang percaya itu menunaikan amanatnya (utangnya)..."

\footnotetext{
${ }^{15}$ Maksudnya: Tuhan akan mengampuni budak-budak wanita yang dipaksa melakukan pelacuran oleh tuannya itu, selama mereka tidak mengulangi perbuatannya itu lagi.

${ }^{16}$ Ialah sebanyak suku Bani Israil sebagaimana tersebut dalam surat Al A'raaf ayat 160.
} 
e) الدعاء (doa), seperti firman Allah swt sebagai berikut

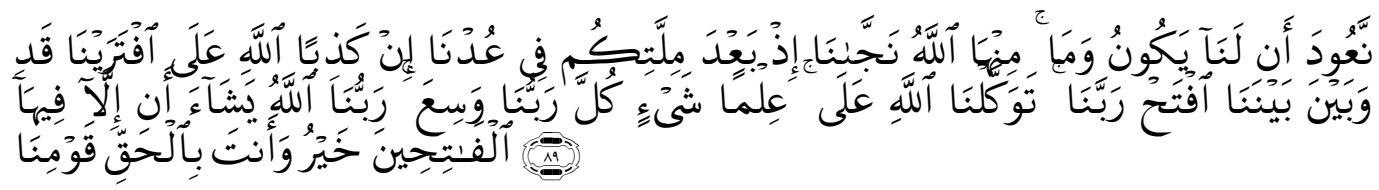

Terjemahnya:

Sungguh kami mengada-adakan kebohongan yang benar terhadap Allah, jika kami kembali kepada agamamu, sesudah Allah melepaskan kami dari padanya. dan tidaklah patut kami kembali kepadanya, kecuali jika Allah, Tuhan kami menghendaki(nya). pengetahuan Tuhan kami meliputi segala sesuatu. kepada Allah sajalah kami bertawakkal. Ya Tuhan kami, berilah Keputusan antara kami dan kaum kami dengan hak (adil) dan Engkaulah pemberi Keputusan yang sebaik-baiknya.

Menurut Tajuddin as-Subki yang diketahui menganut sebagai ulama ushul fiqhi yang mazhab Syafi'i mengatakan bahwa paling tidak ada 26 makna لامر yang dijumpai dalam Alquran. Disampin yang telah disebutkan di atas, الامز juga berarti peringatan, keheranan, izin, pendelegasian dan persamaan ${ }^{17}$.

b. النهي (larangan)

Lafal النهي ini adalah salah satu bentuk perintah syarak yang mengacu kepada larangan untuk berbuat.

Ahli ushul fiqih mengemukakan pengertian النهي sebagai suatu tuntutan secara pasti untuk meninggalkan suatu perbuatan. Jumhur ulama ushul fiqih termasuk Muhammad bin Ali as-Syaukani menambahkan pengertian النهي tersebut dengan kalimat "melalui perintah dari atas" maksudnya tuntutan secara pasti untuk meninggalkan suatu perbuatan itu harus datang dari pihak yang lebih tinggi kedudukannya dibandingkan dengan pihak yang dilarang seperti yang dijelaskan dalam surat al-Baqarah (2): 188 sebagai berikut:

\footnotetext{
${ }^{17}$ Dahlan, Abul Aziz, Ensiklopedi Islam, Op cit., h. 108
} 


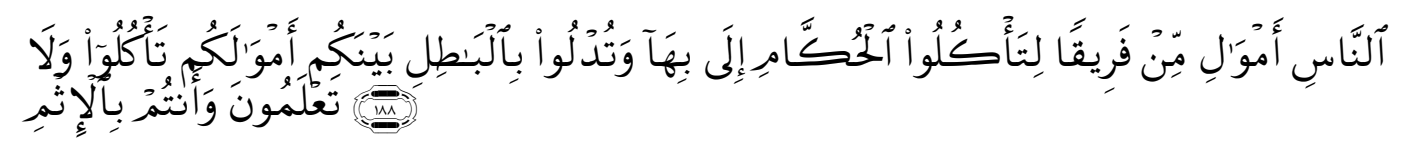

Terjemahnya:

Dan janganlah sebahagian kamu memakan harta sebahagian yang lain di antara kamu dengan jalan yang bathil dan (janganlah) kamu membawa (urusan) harta itu kepada hakim, supaya kamu dapat memakan sebahagian daripada harta benda orang lain itu dengan (jalan berbuat) dosa, padahal kamu Mengetahui.

Dalam kasus ini perintah tersebut datang dari yang maha tinggi, yang posisinya jauh lebih tinggi dari orang yang di perintah. Demikian juga sabda Rasulullah saw yang diriwayatkan oleh Bukhari dan Muslim yang artinya: "tidak halal bagi seorang laki-laki meminang wanita yang telah dipinang laki-laki lain". Dalam kasus ini pun larangan untuk melakukan peminangan itu datang dari orang yang statusnya lebih tinggi dibandingkan dengan orang yang di larang.

Bagi Ibnu as-Subki ahli ushul fiqih yang bermazhab Syafi'i dan sebagian ulama mazhab Maliki yang mengatakan bahwa tuntutan untuk berbuat itu tidak harus datang dari atas atau yang lebih tinggi posisinya dari yang dilarang ${ }^{18}$. Ada tujuh pengertian yang dapat ditunjukkan sebagai ungkapan النهي diatantaranya:

a) التحريم (mengharamkan) contonya firman Allah swt yang terdapat dalam surat al-An'am (6) ayat 151 sebagai berikut:

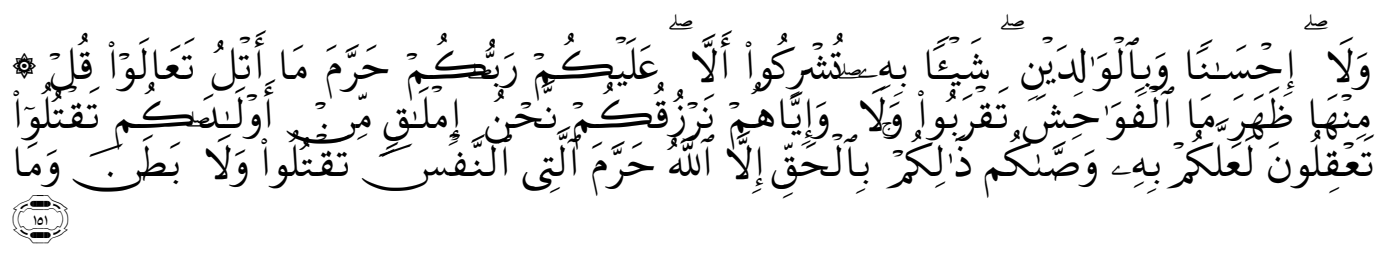

Terjemahnya:

Katakanlah: "Marilah kubacakan apa yang diharamkan atas kamu oleh Tuhanmu yaitu: janganlah kamu mempersekutukan sesuatu dengan Dia, berbuat baiklah terhadap kedua orang ibu bapa, dan janganlah kamu membunuh anak-anak kamu Karena takut kemiskinan, kami akan memberi

${ }^{18}$ Ibid 
rezki kepadamu dan kepada mereka, dan janganlah kamu mendekati perbuatan-perbuatan yang keji, baik yang nampak di antaranya maupun yang tersembunyi, dan janganlah kamu membunuh jiwa yang diharamkan Allah (membunuhnya) melainkan dengan sesuatu (sebab) yang benar ${ }^{19}$. demikian itu yang diperintahkan kepadamu supaya kamu memahami(nya).

Dalam ayat ini di nyatakan bahwa mengharamkan manusia menyembah selain kepada Allah karena diketahui bahwa Allah lah pencipta alam semesta serta segala yang ada didalamya (Tuhan yang esa)

b) اكراهة (membenci) hal ini terdapat dalam sabda Rasulullah saw yang artinya:" seseorang jangan memegang kemaluannya dengan tangan kanan ketika ia buang air kecil" yang ditahrij oleh al-Bukhari, abu Dawud, at-Tirmidzi, an-Nasa'i dan ibnu Majah. Dalam hal ini pemakalah tidak bisah mengatakan sahih atau tidaknya karena tidak menelusurinya secara detail baik sanad serta matannya apakah bisa dijadikan hujjah atau tidak.

c) الدعاء doa) sebagaimana yang terdapat dalam surat al-Baqarah(2) ayat 286 sebagai barikut:

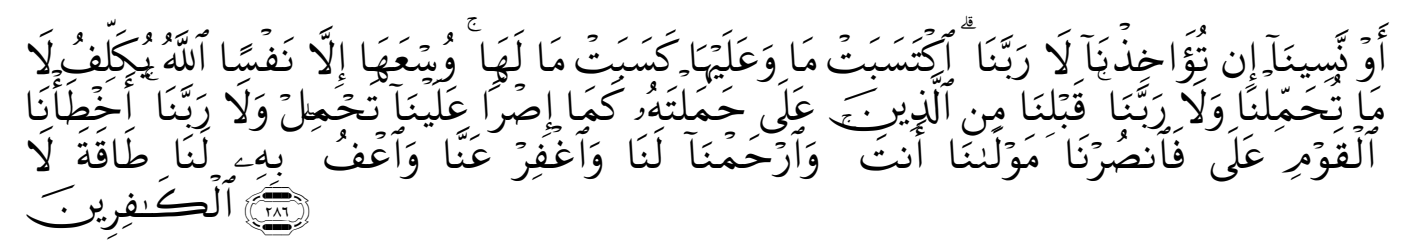

Terjemahnya:

Allah tidak membebani seseorang melainkan sesuai dengan kesanggupannya. ia mendapat pahala (dari kebajikan) yang diusahakannya dan ia mendapat siksa (dari kejahatan) yang dikerjakannya. (mereka berdoa): "Ya Tuhan kami, janganlah Engkau hukum kami jika kami lupa atau kami tersalah. Ya Tuhan kami, janganlah Engkau bebankan kepada kami beban yang berat sebagaimana Engkau bebankan kepada orang-orang sebelum kami. Ya Tuhan kami, janganlah Engkau pikulkan kepada kami apa yang tak sanggup kami

\footnotetext{
${ }^{19}$ Maksudnya yang dibenarkan oleh syara' seperti qishash membunuh orang murtad, rajam dan sebagainya.
} 
memikulnya. beri ma'aflah Kami; ampunilah Kami; dan rahmatilah kami. Engkaulah penolong kami, Maka tolonglah kami terhadap kaum yang kafir."

Dari terjemahan yang saya garis bawahi di atas menandakana bahwa memohon supaya dia tidak dihukum dalam artian dia berdoa supaya dia tidak mendapatka siksaan dari Allah SWT.

d) التحقير (melecehkan atau menghina) sebagaimana firman allah dalam surat alhijr(15) ayat 88 sebagai berikut:

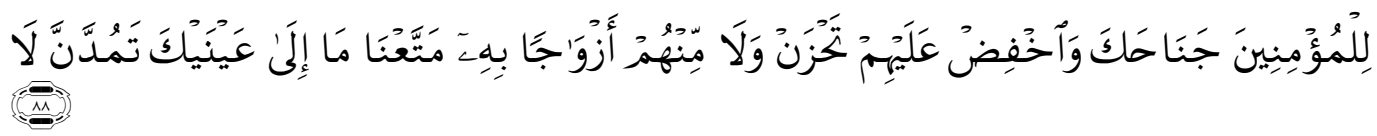

Terjemahnya:

Janganlah sekali-kali kamu menunjukkan pandanganmu kepada kenikmatan hidup yang Telah kami berikan kepada beberapa golongan di antara mereka (orang-orang kafir itu), dan janganlah kamu bersedih hati terhadap mereka dan berendah dirilah kamu terhadap orang-orang yang beriman.

e) بيان العقا ب) (Penjelasan Hukuman) sebagaimana yang terdapat dalam surat Ibrahim (14) ayat 42 sebagai berikut:

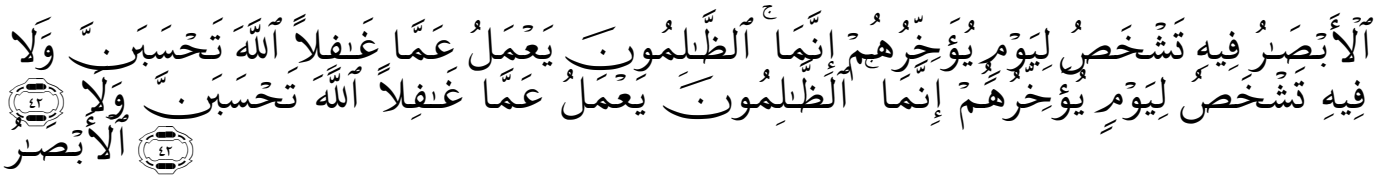

Terjemahnya:

dan janganlah sekali-kali kamu (Muhammad) mengira, bahwa Allah lalai dari apa yang diperbuat oleh orang-orang yang zalim. Sesungguhnya Allah memberi tangguh kepada mereka sampai hari yang pada waktu itu mata (mereka) terbelalak, 
f) الارشاد (bimbingan) sebagaimana yang terdapat dalam surat al-Maidah(5) ayat 101 sebagi berikut:

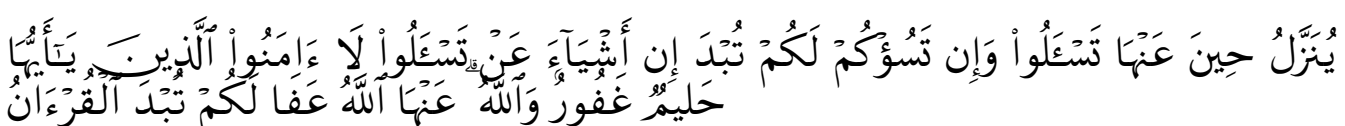

Terjemahnya:

Hai orang-orang yang beriman, janganlah kamu menanyakan (kepada Nabimu) hal-hal yang jika diterangkan kepadamu akan menyusahkan kamu dan jika kamu menanyakan di waktu Al Quran itu diturunkan, niscaya akan diterangkan kepadamu, Allah memaafkan (kamu) tentang hal-hal itu. Allah Maha Pengampun lagi Maha Penyantun.

g) (membuat putus asa) sebagaimana firman Allah dalam surat al-Tahrim(66) ayat 7 sebagai berikut:

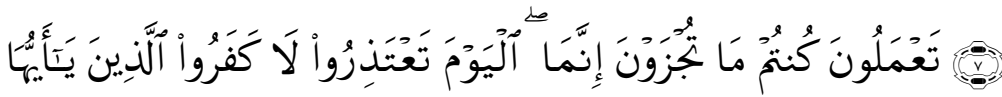

Terjemahnya:

Hai orang-orang kafir, janganlah kamu mengemukakan uzur pada hari ini. Sesungguhnya kamu Hanya diberi balasan menurut apa yang kamu kerjakan.

Jumhur ulama mengatakan bahwa hakikat makna التحريم adalah النهي (mengharamkan) sedakan selain makna tersebut tersebut adalah makna majasi saja. Menurut mereka ungkapan النهي menghendaki suatu perbuatan yang dilarang dan perbuatan itu mesti dihentikan. Apabila ungkapan النهي itu tidak pasti dan mengandung qarĩnah(indikasi) yang memalingkan makna dari larangan yang pasti, makna الكراحة النهي (membenci) sebagaiman yang terdapat dalam surat al-Maidah(5) ayat 87 sebagai berikut:

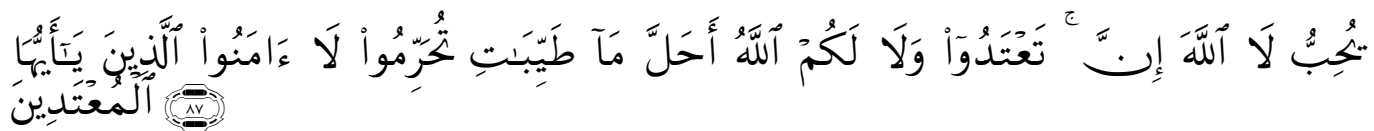


Terjemahnya:

Hai orang-orang yang beriman, janganlah kamu haramkan apa-apa yang baik yang Telah Allah halalkan bagi kamu, dan janganlah kamu melampaui batas. Sesungguhnya Allah tidak menyukai orang-orang yang melampaui batas.

Menurut jumhur ulama larangan dalam ayat ini menunjukkan hukum makruh, karena adanya indikasi bahwa ada saatnya sesuatu yang baik itu menjadi tidak baik bagi peribadi tertentu. Oleh karena itu tidak bisa hukum larangan dalam suatu ayat dipastikan sebagai haram. Alasannya sebagaimana yang dikemukakan oleh jumhur ulama sebagimana firman Allah yang dikemukakan dalam surat al-Hasyr(59) ayat 7 sebagai berikut:

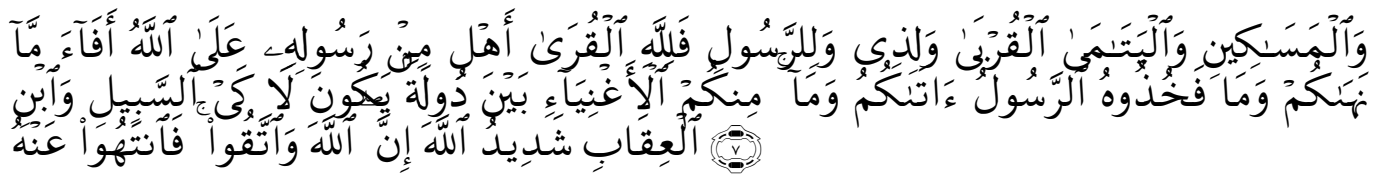

Terjemahnya:

Apa saja harta rampasan (fai-i) yang diberikan Allah kepada RasulNya (dari harta benda) yang berasal dari penduduk kota-kota Maka adalah untuk Allah, untuk rasul, kaum kerabat, anak-anak yatim, orang-orang miskin dan orangorang yang dalam perjalanan, supaya harta itu jangan beredar di antara orangorang Kaya saja di antara kamu. apa yang diberikan Rasul kepadamu, Maka terimalah. dan apa yang dilarangnya bagimu, Maka tinggalkanlah. dan bertakwalah kepada Allah. Sesungguhnya Allah amat keras hukumannya.

Dalam ayat ini dapat dipahami bahwa Allah Swt memerintahkan untuk meninggalkan sesuatu yang dilarang. Oleh sebab itu jumhur ulama berperndirian bahwa setiap larangan baik yang berdalil qat'i(pasti) maupun zanni(tidak jelas dan tegas) periwayat maupun kandungannya menunjukkan perbuatan itu dilarang secara pasti.

\section{Kesimpulan}

Kata النهي lafal ini masing-masing antonim antara keduanya mempunyai tuntutan yang sama, الامـر adalah tuntutan yang wajib dilaksanakan sedangkan النهي adalah kewajiban untuk meninggalkan sesuatu. Jadi pada hekekatnya sama-sama tuntutan yang pada dasarnya datangnya dari seseuatu yang lebih tinggi atau tertinggi adapun banyak perubahan arti baik dari الامر maupun perubahan dari itu adalah makna majasi saja. 


\section{DAFTAR PURTAKA}

al-Tsabit, Khalid bin Usman, Muhtasar Fi Qawaid Al-Tafsir(Dar Ibnu Affan Li AlNasyri Wa Al-Tauziq, 1996 M)

-------------------------, Qawaid al-Tafsir, jilid 2 (cet. I;Al-Mumlikat Al-Arabi Saudi: Dar Ibnu Affan Li Al-Nasry Wa Al-Tauziq, 1997 M).

Abul Aziz Dahlan, Ensiklopedi Islam, (cet. I; Jakarta: Ichtiar Baru Van Hoeve, 1996).

al-Qattan. Manna' Khalil, Studi Ilmu-Ilmu Al-Quran, (cet. VI; Bogor: Pustaka Litera Antar Nusa, 2001)

Ahmad Bin Faris Bin Zakiyah, Abi Husein, Makayisu Al-Lugah, juz I (Daru al-Fikri,) Dahlan. Abd. Rahman, Kaidah-Kaidah Penafsiran Alquran, (cet. II; Bandung: Mizan, 1998). H. 304

Shihab, Umar, Kontekstualitas Alquran Kajian Tematik Atas Ayat-Ayat Hukum Dalam Alquran,(cet. I; Jakarta: Penamadani, 2003)

Suryadilaga Al-Fatih, Pengantar Abd. Muin Salim, Metodologi Ilmu Tafsir, (Cet. I; Yogyakarta: Teras, 2005) h.97 